\title{
EVALUASI PENGUJIAN VIBRASI STRUKTUR (STUDI KASUS : DERMAGA DONGGALA)
}

\author{
Devlin Tedy $^{1}$, Wiryanto Dewobroto ${ }^{2}$ \\ ${ }^{1}$ Mahasiswa Program Studi Magister Teknik Sipil, Universitas Tarumanagara, Jakarta \\ Email:d_tedy@hotmail.com \\ ${ }^{2}$ Dosen Program Studi Teknik Sipil, Universitas Pelita Harapan, Tangerang \\ Email:wiryanto.dewobroto@uph.edu
}

Masuk: 11-12-2018, revisi: 28-06-2019, diterima untuk diterbitkan: 13-08-2019

\begin{abstract}
ABSTRAK
Setiap struktur memiliki perilaku dinamik berupa frekuensi alami yang dapat dicari dengan uji vibrasi di lapangan secara empiris dan analisis numerik. Frekuensi alami terdiri dari massa, kekakuan, dan arah (mode shape). Parameter-parameter tersebut menghasilkan banyak variasi model struktur. Model yang paling tepat dengan kondisi lapangan dapat dicari dengan bantuan hasil uji vibrasi yang berfungsi sebagai kalibrator. Dalam mencari frekuensi alami melalui uji vibrasi sangat tergantung pada teknologi seperti tipe sensor dan cara penempatannya yang digunakan untuk merekam getaran yang diberikan. Tipe sensor terdiri dari berbagai macam seperti uniaxial, biaxial, dan triaxial. Pada kasus uji vibrasi struktur dermaga Donggala menggunakan 6 buah sensor accelerometer uniaxial. Sensor dipasang dalam 3 tempat berbeda masing-masing tempat dalam arah lateral dan vertikal. Hasil pengujian dari pihak surveyor didalam mengevaluasi hasilnya hanya rata-rata tanpa memperhitungkan pengaruh arah. Hal ini yang akan dievaluasi pada penelitian ini. Evaluasi yang akan dilakukan adalah membandingkan hasil pengujian vibrasi dengan analisis numerik. Dari berbagai model analisis numerik dapat diketahui bahwa meskipun nilai frekuensi alaminya bervariasi tetapi masih didalam batas nilai tertentu. Dengan melihat apakah arah penempatan sensor dan arah tumbukan kapal, maka dapat diprediksi perilaku dinamik dermaga apakah translasi atau rotasi yang terjadi. Dengan demikian evaluasi yang digunakan oleh surveyor dengan melakukan rata-rata tanpa melihat arah adalah tidak tepat. Oleh sebab itu akan dilakukan evaluasi ulang mempelajari arah pemberian gaya, arah pemasangan dan penempatan sensor accelerometer serta perlu melakukan pengelompokan hasil pengujian vibrasi berdasarkan arah sensor. Setelah mempelajari model numerik dari dermaga dapat diketahui bahwa model numerik yang bertranslasi mempunyai kesesuaian dengan data tumbukan pada salah satu titik sensor yang dipasang. Pemodelan numerik yang mendekati nilai ini adalah sesuai dengan data perencanaan sebelumnya. Dari penelitian ini dapat diketahui bahwa pemahaman pengujian vibrasi perlu dilakukan pengelompokan sesuai arah penempatan sensor dan tidak dapat dilakukan rata-rata.
\end{abstract}

Kata Kunci: pengujian vibrasi; analisis numerik; frekuensi alami

\begin{abstract}
Each structure has dynamic behavior in the form of natural frequencies that can be searched by vibration testing in the field empirically and numerical analysis. Natural frequency consists of mass, stiffness, and direction (shape mode). These parameters produce many variations of the structural model. The most appropriate model with field conditions can be sought with the help of vibration test results that function as a calibrator. In searching for natural frequencies through vibration testing it is very dependent on technology such as the type of sensor and the way it is used to record the vibrations given. Sensor types consist of various types such as uniaxial, biaxial, and triaxial. In the case of vibration test the Donggala pier structure uses 6 uniaxial accelerometer sensors. Sensors are installed in 3 different places each in lateral and vertical directions. Test results from the surveyor in evaluating the results are only average without taking into account the influence of direction. This will be evaluated in this study. The evaluation will be done is to compare the results of vibration testing with numerical analysis. From various numerical analysis models, it can be seen that although the natural frequency values vary, they are still within certain limits. By looking at the direction of the placement of the sensor and the direction of the collision of the ship, it can be predicted the dynamic behavior of the pier whether translation or rotation is happening. Thus the evaluation used by the surveyors by averaging without looking at directions is incorrect. Therefore a re-evaluation will be conducted to study the direction of the force, the direction of the placement and placement of the accelerometer sensor and the need to group the results of vibration testing based on the sensor direction. After studying the numerical model from the dock, it can be seen that the numerical model that translates has conformity to the collision data at one of the installed sensor points. Numerical modeling which is close to this value is in accordance with previous planning data. From this research it can be seen that the understanding of vibration testing needs to be grouped according to the direction of the sensor placement and cannot be carried out on average.
\end{abstract}

Keywords: vibration testing; numerical analysis; natural frequency 


\section{PENDAHULUAN}

Setiap struktur memiliki perilaku dinamik berupa frekuensi alami yang dapat dicari dengan pengujian dinamik di lapangan dan analisis numerik. Penelitian terkait dengan pengujian dinamik saat ini cukup populer atau banyak dijumpai. Pengujian dinamik di lapangan dilakukan secara non-destructive dengan metode uji vibrasi menggunakan sensor accelerometer untuk mengukur respons struktur terhadap beban dinamik yang diberikan dalam percobaan (Morassi 2008; Brownjohn 2010; Jeary et al 2015). Menurut Setareh (2010) properti dinamik struktur yang digunakan antara pengujian di lapangan dan analisis numerik harus dibandingkan dan dicari korelasi antar keduanya. Terkait dengan penelitian dinamik tersebut maka penggunaan model elemen hingga menjadi sangat penting untuk memprediksi perilaku dinamik struktur (Abdeljaber et al 2016; Avci 2012; Avci 2015; Avci \& Davis 2015; Davis \& Avci 2015; Setareh \& Gan 2018).

Pengujian dinamik telah dilakukan pada struktur dermaga yang terletak di Kabupaten Donggala, Provinsi Sulawesi Tengah. Gambar aktual dermaga dapat dilihat pada Gambar 1.

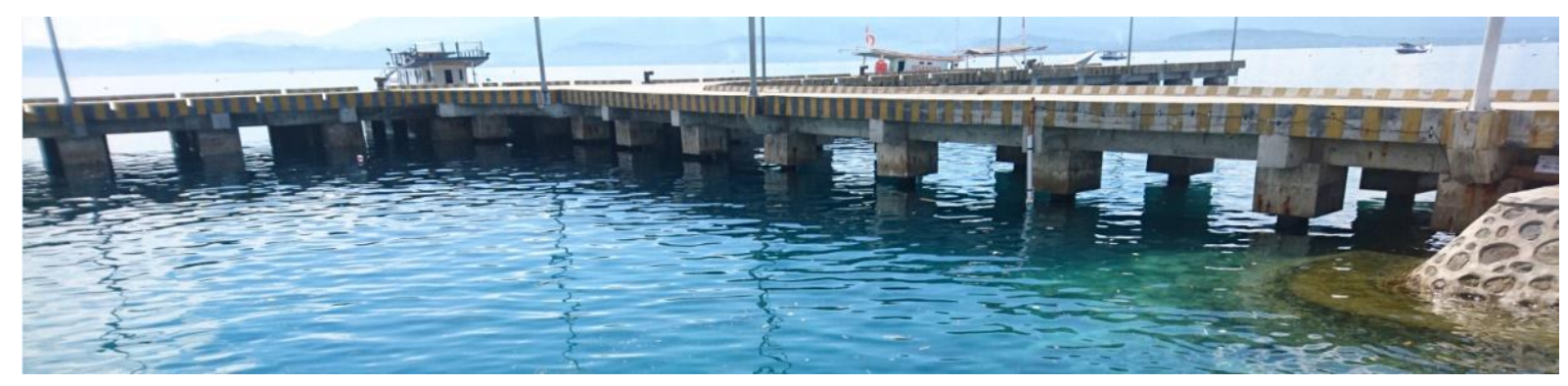

Gambar 1. Dermaga Donggala

Dermaga Donggala terdiri dari 2 bagian segmen yang dipisah oleh dilatasi selebar $50 \mathrm{~mm}$. Gambar layout dermaga ini dapat dilihat pada Gambar 2.

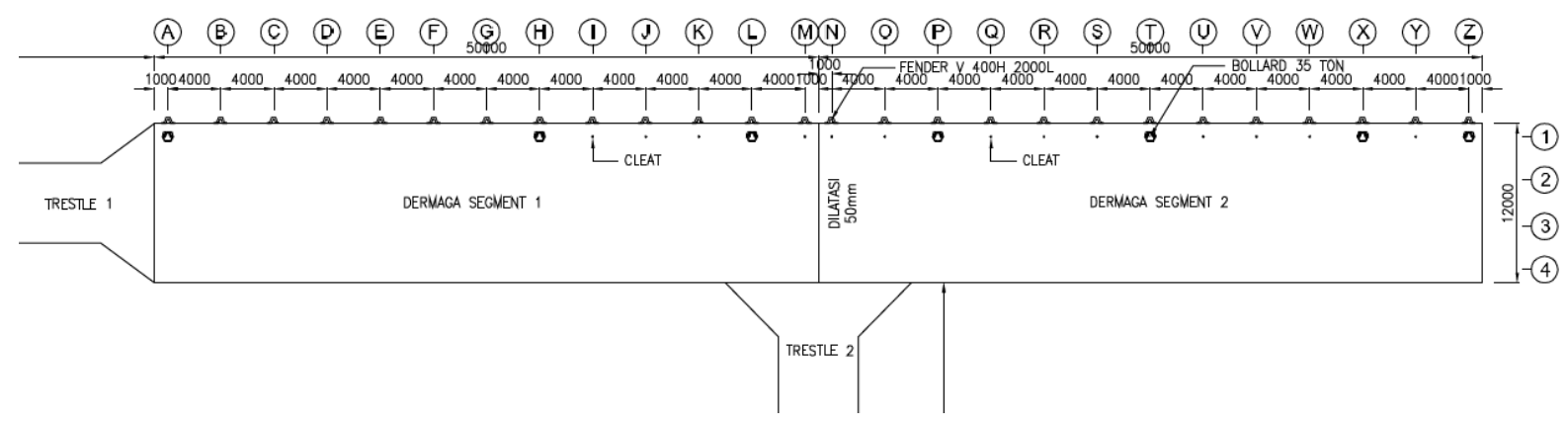

Gambar 2. Layout Dermaga Donggala

Jumlah sensor accelerometer yang digunakan pada pengujian struktur dermaga ini sebanyak 6 buah dengan tipe uniaxial. Beban dinamik yang diberikan pada pengujian adalah tumbukkan kapal. Kapal yang digunakan untuk pengujian dapat dilihat pada Gambar 3. Hasil dari pengujian vibrasi dapat dilihat pada Tabel 1. Denah struktur dermaga dan letak sensor accelerometer tersebut dapat dilihat pada Gambar 4. Sensor accelerometer dapat dilihat pada Gambar 5. Arah tumbukan kapal dalam uji vibrasi dapat dilihat pada Gambar 6. 


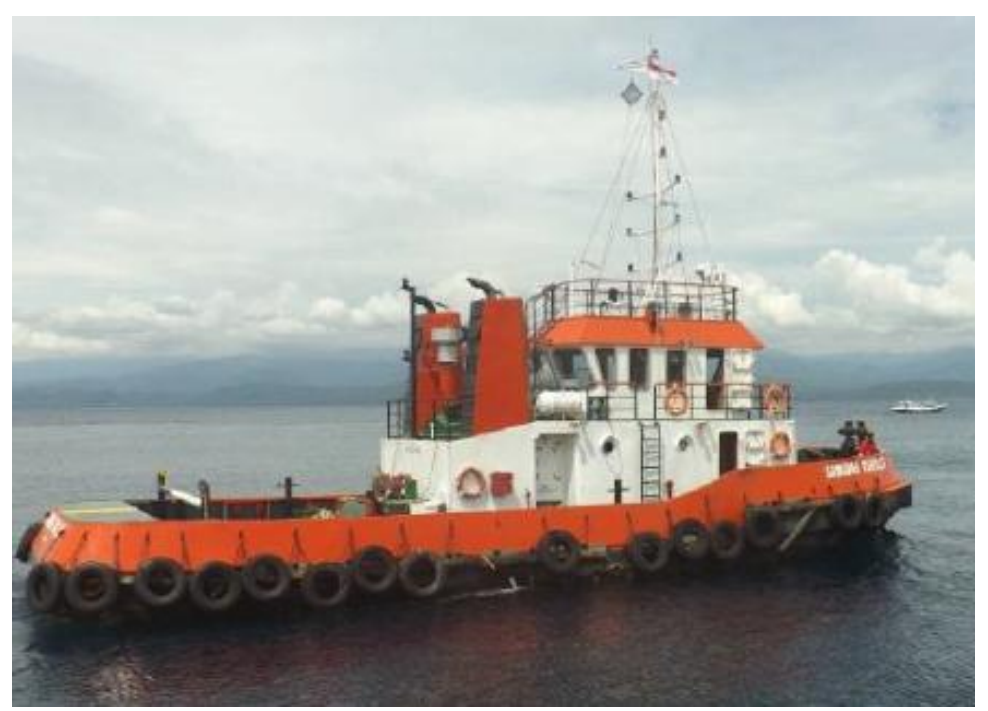

Gambar 3. Kapal Untuk Tumbukan Uji Vibrasi

Tabel 1. Rangkuman Hasil Pengujian Vibrasi Struktur Dermaga (GSI 2016)

\begin{tabular}{cccc}
\hline \multirow{2}{*}{ No. Sensor } & Frekuensi Alami & Frekuensi Alami & Frekuensi Alami \\
\cline { 2 - 4 } & $($ Tumbukan 1) & $($ Tumbukan 2) & (Tumbukan 3) \\
\cline { 2 - 4 } & $(\mathrm{Hz})$ & $(\mathrm{Hz})$ & $(\mathrm{Hz})$ \\
\hline Acc 1 & 0,98 & 0,98 & 1,7 \\
\hline Acc 2 & 0,73 & 1,5 & 1,5 \\
\hline Acc 3 & 0,98 & 0,98 & 0,98 \\
\hline Acc 4 & 1,7 & 1,7 & 0,98 \\
\hline Acc 5 & 1,2 & 0,98 & 0,98 \\
\hline Acc 6 & 1,5 & 0,98 & 0,98 \\
\hline Rata-rata & 1,2 & 1,2 & 1,2 \\
\hline
\end{tabular}

Tabel 1 adalah hasil laporan pengujian dimana nilainya ditentukan dengan rata-rata oleh surveyor. Padahal menurut penelitian Conte et al (2008) akselerasi dan getaran memiliki arah sehingga kurang tepat untuk merata-rata hasil akselerasi dengan arah yang berbeda. Untuk membuktikan bahwa rata-rata itu kurang tepat maka akan dilakukan evaluasi ulang penelitian ini.

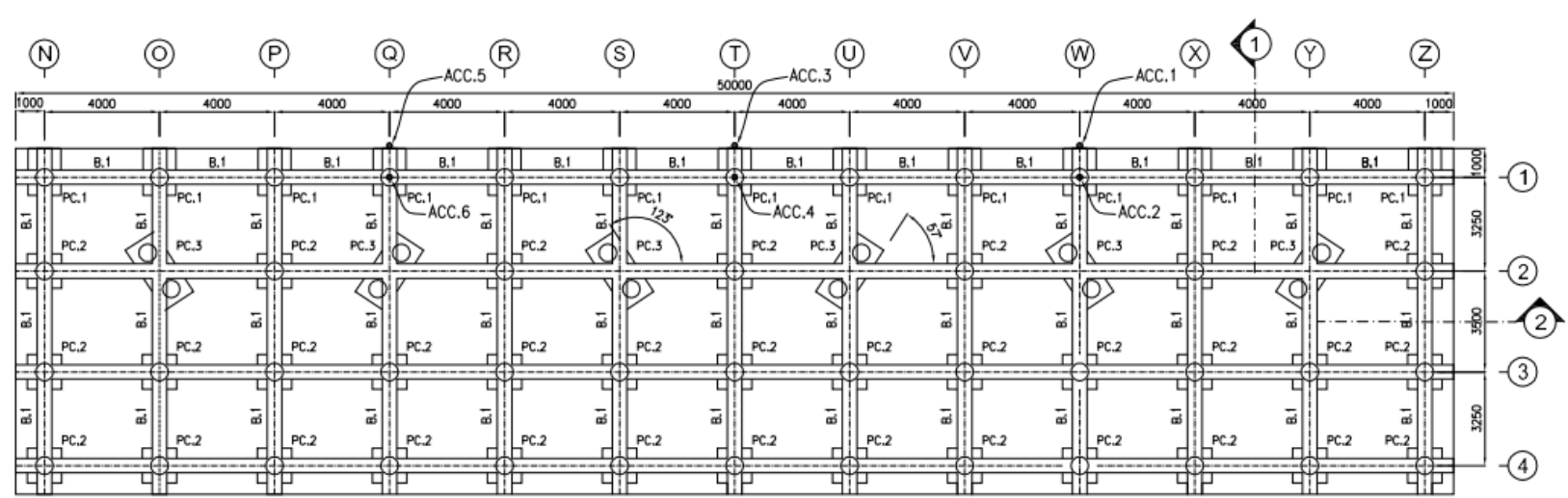

Gambar 4. Lokasi Sensor Accelerometer Pada Denah Struktur Dermaga 


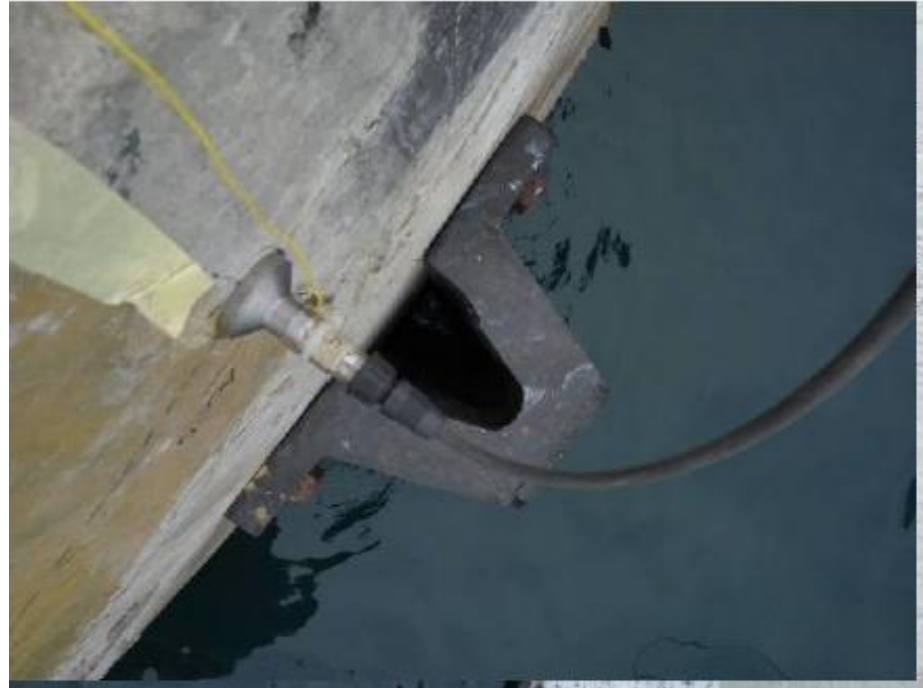

(a)

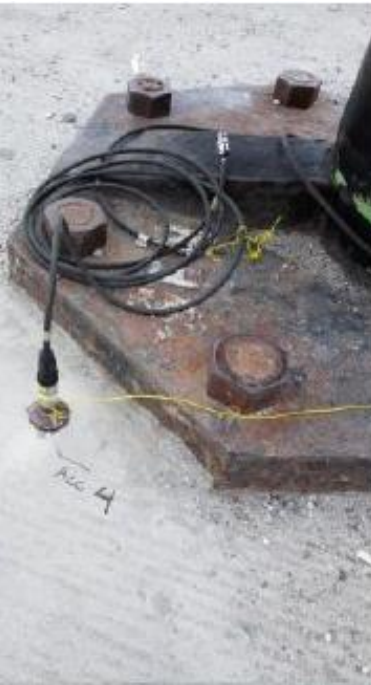

(b)

Gambar 5. Pemasangan Sensor Accelerometer (a) Arah Lateral dan (b) Arah Lantai Dermaga

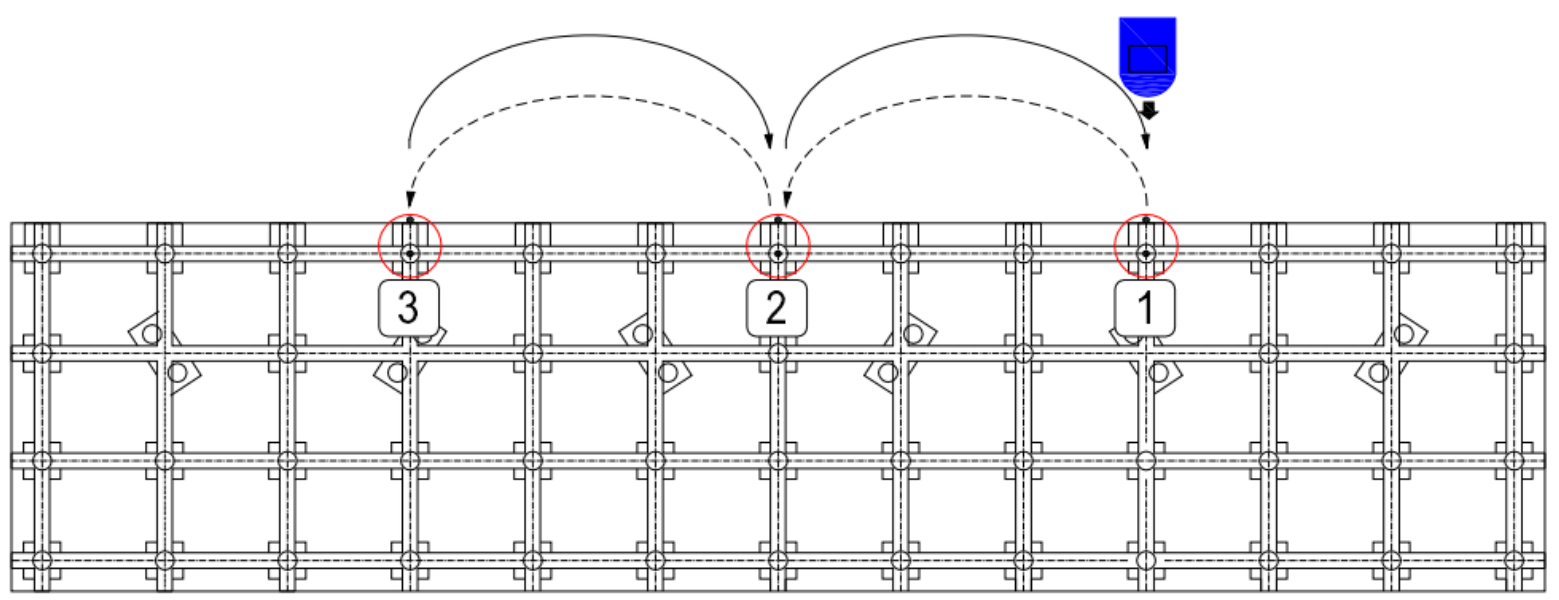

Gambar 6. Arah Tumbukan Kapal Dalam Uji Vibrasi

\section{EVALUASI ULANG HASIL UJI VIBRASI STRUKTUR DERMAGA DONGGALA}

Berdasarkan dari pernyataan Conte et all (2008), frekuensi alami terdiri mode getaran sebagai vektor pada bidang kompleks yang menunjukkan akselerasi dan getaran memiliki arah. Dalam proses pengujian vibrasi menggunakan kapal pada posisi dimana akibat tumbukan struktur dermaga mengalami deformasi berupa translasi lateral. Oleh sebab itu data-data hasil pengujian perlu dikelompokan sesuai dengan arahnya. Hasil pengelompokan nilai frekuensi alami dari pengujian dapat dilihat pada Tabel 2 dan Tabel 3.

Sesuai dengan jenis sensor yang digunakan pada pengujian ini maka nilai frekuensi alami yang diambil hanya berdasarkan dari arah tumbukan kapal (lateral) dimana hasil tersebut terdiri dari acc 1, acc 3, dan acc 5 yang dapat dilihat pada Tabel 2. 
Tabel 2. Rangkuman Hasil Pengelompokan Sensor Accelerometer Pada Arah Lateral Dermaga

\begin{tabular}{|c|c|c|c|c|}
\hline \multirow{2}{*}{ No. Sensor } & $\begin{array}{c}\text { Tumbukan Pada } \\
\text { Titik } 1\end{array}$ & $\begin{array}{c}\text { Tumbukan Pada } \\
\text { Titik } 2\end{array}$ & $\begin{array}{c}\text { Tumbukan Pada } \\
\text { Titik } 3\end{array}$ & \multirow{2}{*}{ Keterangan } \\
\hline & $\begin{array}{c}\text { Frekuensi } \\
\text { Alami (Hz) }\end{array}$ & $\begin{array}{l}\text { Frekuensi } \\
\text { Alami }(\mathrm{Hz})\end{array}$ & $\begin{array}{c}\text { Frekuensi } \\
\text { Alami }(\mathrm{Hz})\end{array}$ & \\
\hline Acc 1 & 0,98 & 0,98 & 1,7 & \multirow{3}{*}{ Lateral } \\
\hline Acc 3 & 0,98 & 0,98 & 0,98 & \\
\hline Acc 5 & 1,2 & 0,98 & 0,98 & \\
\hline Acc 2 & 0,73 & 1,5 & 1,5 & \multirow{3}{*}{ Vertikal } \\
\hline Acc 4 & 1,7 & 1,7 & 0,98 & \\
\hline Acc 6 & 1,5 & 0,98 & 0,98 & \\
\hline
\end{tabular}

Hipotesis perilaku dinamik berdasarkan tumbukan kapal :

a. Pada saat kapal menumbuk Titik 1 maka Titik 1 dan Titik 2 mengalami deformasi yang lebih besar dari Titik 3. Akibat perbedaan tersebut seakan-akan bangunan dermaga mengalami rotasi

b. Pada saat kapal menumbuk Titik 2 maka Titik 1, Titik 2, dan Titik 3 mengalami deformasi yang sama karena tumbukan kapal dilakukan di tengah dermaga sehingga mengalami translasi.

c. Pada saat kapal menumbuk Titik 3 makaTitik 2 dan Titik 3 mengalami deformasi yang besar dan menumbuk bangunan lain yaitu trestle. Oleh sebab itu maka Titik 1 mengalami deformasi yang lebih kecil.

\section{STUDI PARAMETRIK ANALISIS NUMERIK DERMAGA DONGGALA}

Dari uraian pada pembahasan pengujian vibrasi terkesan bahwa bangunan mengalami translasi dan rotasi. Untuk membuktikannya maka akan dilakukan analisis numerik. Dalam analisis numerik tersebut akan dimodelkan sebagai suatu struktur dermaga 1 segmen yang sederhana yang bagian atas adalah pelat dan bagian bawah adalah suatu sistem portal yang dapat dilihat dalam denah struktur sebelumnya pada Gambar 4. Konstruksi dermaga terdiri dari konstruksi lantai yang terdiri dari grid balok dan pelat yang berbentuk persegi berukuran $50 \mathrm{~m}$ x $12 \mathrm{~m}$. Dari grid itu kemudian pada simpul grid didukung oleh tiang pancang baja dengan ukuran diameter luar 609,6 mm dan tebal $12 \mathrm{~mm}$. Pelat lantai memiliki tebal $320 \mathrm{~mm}$. Nilai modulus elastisitas untuk tiang pancang sebesar $\mathrm{E}_{\mathrm{s}}=200.000 \mathrm{MPa}$ dan nilai mutu beton untuk penampang pile cap, balok, dan pelat lantai sebesar $\mathrm{fc}=20,75 \mathrm{MPa}$ dengan $\mathrm{E}_{\mathrm{c}}=21.409,519 \mathrm{MPa}$.

Ukuran pile cap yang digunakan memiliki 3 ukuran yaitu dengan panjang x lebar masing-masing $1624 \mathrm{~mm}$ x $1200 \mathrm{~mm}$ untuk ukuran pile cap pertama (PC1) berada pada bagian depan dari dermaga, $1200 \mathrm{~mm} \times 1200 \mathrm{~mm}$ untuk ukuran pile cap kedua (PC2) terletak dibagian tengah dan belakang dermaga dengan jumlah tiang 1 buah, dan $2500 \mathrm{~mm} \times 1200 \mathrm{~mm}$ untuk ukuran pile cap ketiga (PC3) berada dibagian tengah dermaga dengan jumlah tiang 2 buah. Ketiga pile cap ini memiliki tebal yang sama yaitu $900 \mathrm{~mm}$. Ukuran balok (B1) yang digunakan sebesar $500 \mathrm{~mm} \mathrm{x}$ $800 \mathrm{~mm}$ dan tebal pelat lantai adalah $32 \mathrm{~cm}$. 
Setiap pemodelan struktur menghasilkan nilai frekuensi alami yang berbeda. Berdasarkan dari fisik bangunan yang sudah ada akan dibuat berbagai parametrik model yang diuji sebanyak 27. Dimana dalam 27 pemodelan itu ada 3 kelompok besar yaitu model A, B, dan C yang dapat dilihat pada Gambar 7 sampai Gambar 9. Pemodelan model A dilakukan dengan meninjau mode shape translasi. Pemodelan model B dan $\mathrm{C}$ akan meninjau mode shape rotasi. Pada model $\mathrm{B}$ dan $\mathrm{C}$, beberapa titik dari struktur dermaga akan diberikan restraint karena struktur dermaga menabrak struktur lain yang dilatasi $50 \mathrm{~mm}$ saat pemberian beban dinamik tumbukkan kapal. Struktur lain tersebut adalah dermaga segmen 1 dan trestle yang dapat dilihat sebelumnya pada Gambar 2. Untuk model B akan diberikan restraint pada titik yang tertabrak dermaga segmen 1 dan untuk model $\mathrm{C}$ akan diberikan restraint pada titik yang tertabarak trestle. Dari tiap model masing-masing dilakukan parametrik lagi yaitu panjang tiang pancang sampai pada virtual fixed point (M1), komponen struktur balok kaku sekali dan deformasi axial tiang diabaikan (M2), memodelkan spring lateral pada tiang yang masuk kedalam tanah (M3), panjang tiang sampai panjang total dengan perletakan sendi (M4), panjang tiang sampai panjang total dengan perletakan jepit (M5). Rangkuman 27 pemodelan struktur dapat dilihat pada Tabel 5 sampai Tabel 7. Dari 27 model yang paling mendekati dengan hasil pengujian di lapangan ada 2 yaitu model A3 dan C3 yang dapat dilihat pada Gambar 10. Bentuk mode shape dapat dilihat pada Gambar 11.

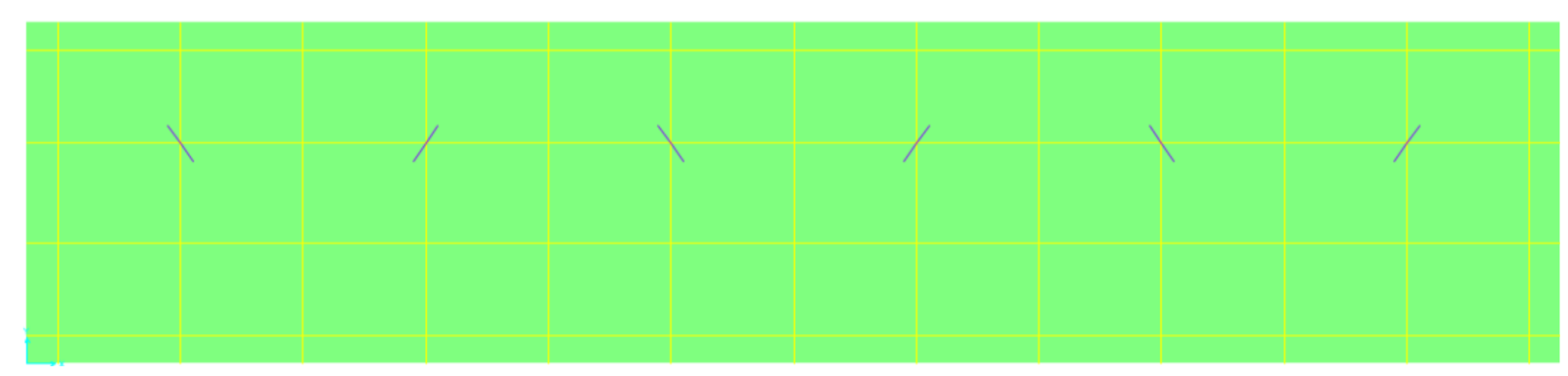

Gambar 7. Model A Pada Program Finite Element

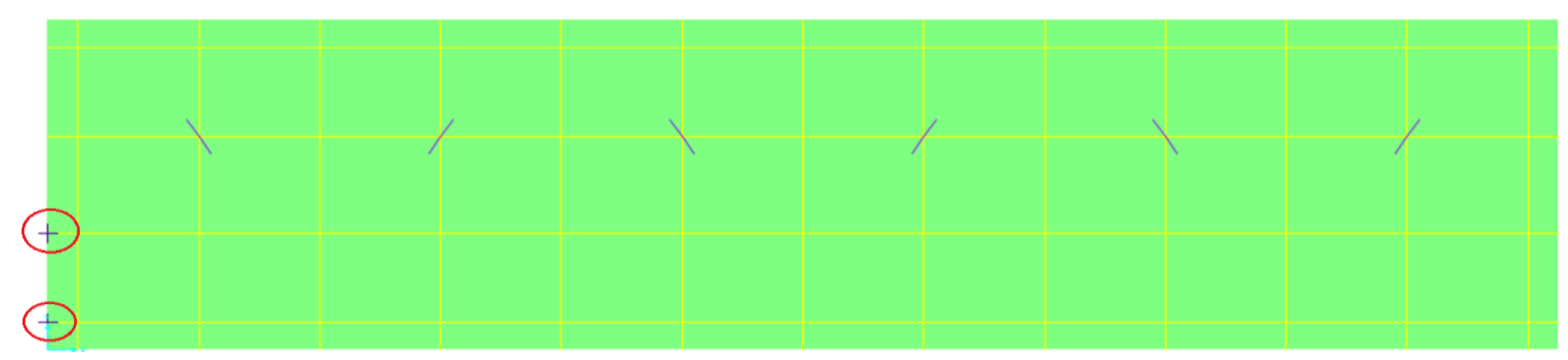

Gambar 8. Model B Program Finite Element (Lingkaran Merah adalah Restraint)

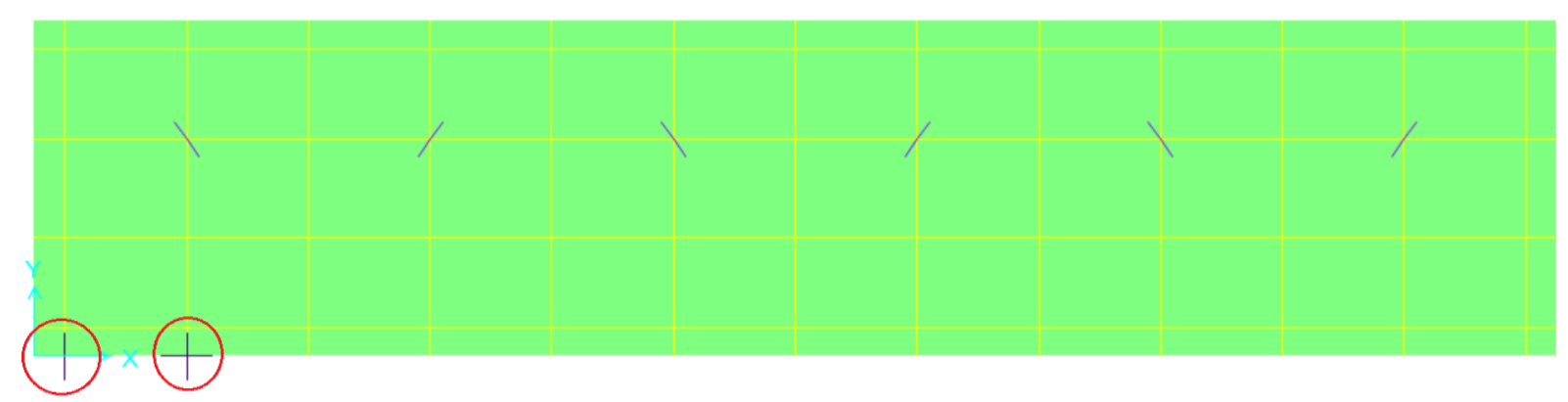

Gambar 9. Model C Program Finite Element (Lingkaran Merah adalah Restraint) 
Tabel 3. Rangkuman Model A (Mode Shape Translasi)

\begin{tabular}{ccl}
\hline Notasi & Hasil $\mathrm{f}(\mathrm{Hz})$ & Parametrik Uji \\
\hline A1 & 0,80783 & M1 \\
\hline A2 & 5,44469 & M1, M2 \\
\hline A3 & 0,90027 & M1, M3 \\
\hline A4 & 5,58692 & M1, M2, M3 \\
\hline A5 & 0,49096 & M5 \\
\hline A6 & 0,7128 & M3, M5 \\
\hline A7 & 4,06031 & M2, M3, M5 \\
\hline A8 & 0,7128 & M3, M4 \\
\hline A9 & 4,06031 & M2, M3, M4
\end{tabular}

Tabel 4. Rangkuman Model B (Mode Shape Rotasi)

\begin{tabular}{ccl}
\hline Notasi & Hasil $\mathrm{f}(\mathrm{Hz})$ & Parametrik Uji \\
\hline B1 & 1,67824 & M1 \\
\hline B2 & 9,36327 & M1, M2 \\
\hline B3 & 1,75835 & M1, M3 \\
\hline B4 & 9,01967 & M1, M2, M3 \\
\hline B5 & 1,52961 & M5 \\
\hline B6 & 1,68886 & M3, M5 \\
\hline B7 & 8,80309 & M2, M3, M5 \\
\hline B8 & 1,6807 & M3, M4 \\
\hline B9 & 8,80238 & M2, M3, M4
\end{tabular}

Tabel 5. Rangkuman Model C (Mode Shape Rotasi)

\begin{tabular}{ccl}
\hline Notasi & Hasil $\mathrm{f}(\mathrm{Hz})$ & Parametrik Uji \\
\hline $\mathrm{C} 1$ & 1,28704 & $\mathrm{M} 1$ \\
\hline $\mathrm{C} 2$ & 5,87221 & $\mathrm{M} 1, \mathrm{M} 2$ \\
\hline $\mathrm{C} 3$ & 1,36649 & $\mathrm{M} 1, \mathrm{M} 3$ \\
\hline $\mathrm{C} 4$ & 6,0238 & $\mathrm{M} 1, \mathrm{M} 2, \mathrm{M} 3$ \\
\hline $\mathrm{C} 5$ & 1,0979 & $\mathrm{M} 5$ \\
\hline $\mathrm{C} 6$ & 1,25776 & $\mathrm{M} 3, \mathrm{M} 5$ \\
\hline $\mathrm{C} 7$ & 4,73633 & $\mathrm{M} 2, \mathrm{M} 3, \mathrm{M} 5$ \\
\hline $\mathrm{C} 8$ & 1,2539 & $\mathrm{M} 3, \mathrm{M} 4$ \\
\hline $\mathrm{C} 9$ & 4,73541 & $\mathrm{M} 2, \mathrm{M} 3, \mathrm{M} 4$
\end{tabular}




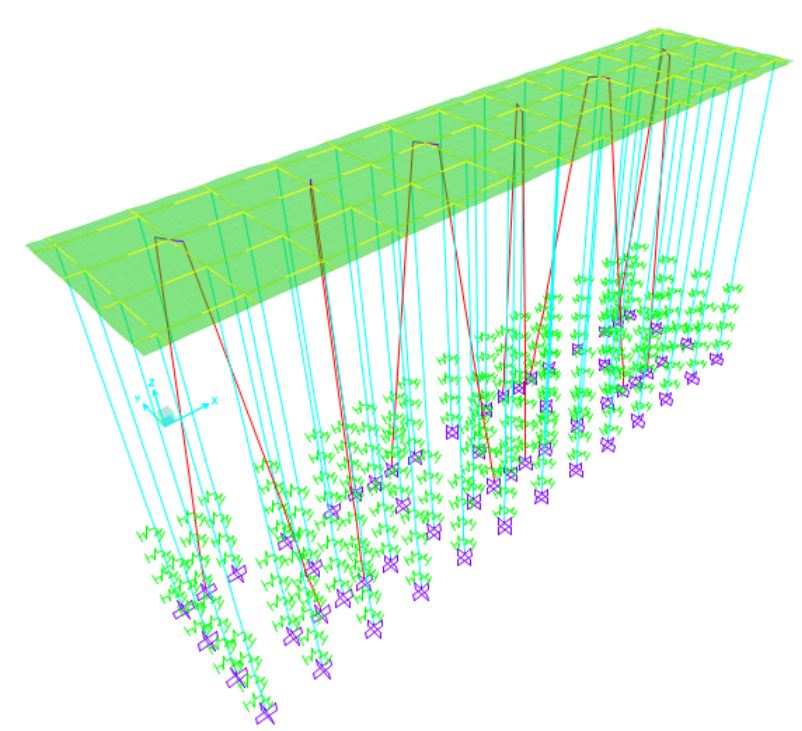

(a)

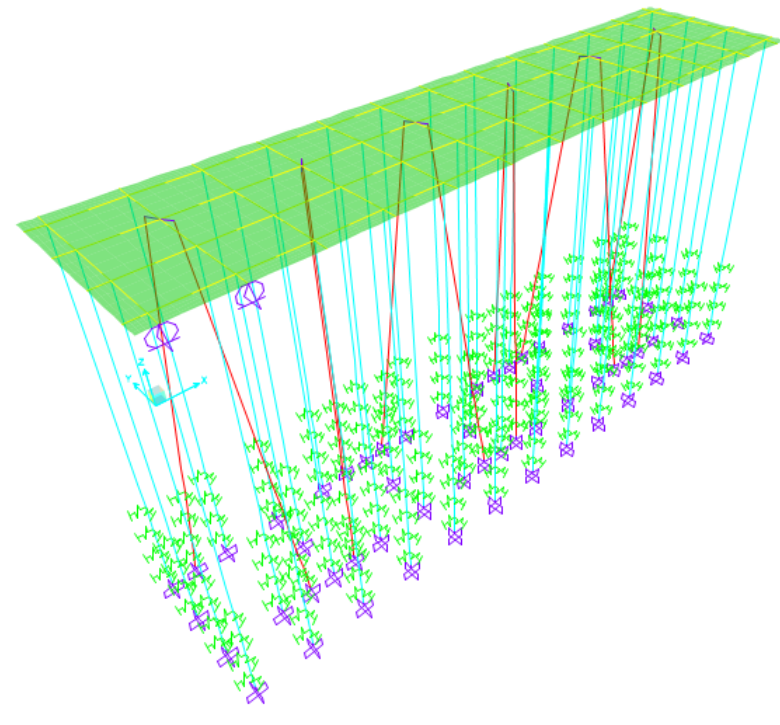

(b)

Gambar 10. Model A3 (a) dan C3 (b) Struktur Dermaga Pada Program Finite Element

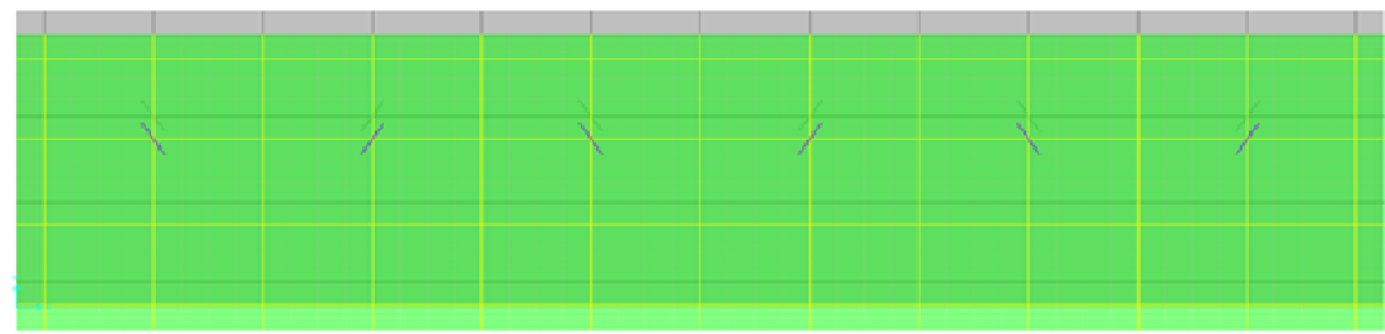

(a) $\mathrm{T}=1.11078 \operatorname{detik} ; \mathrm{f}=0.90027 \mathrm{~Hz}$

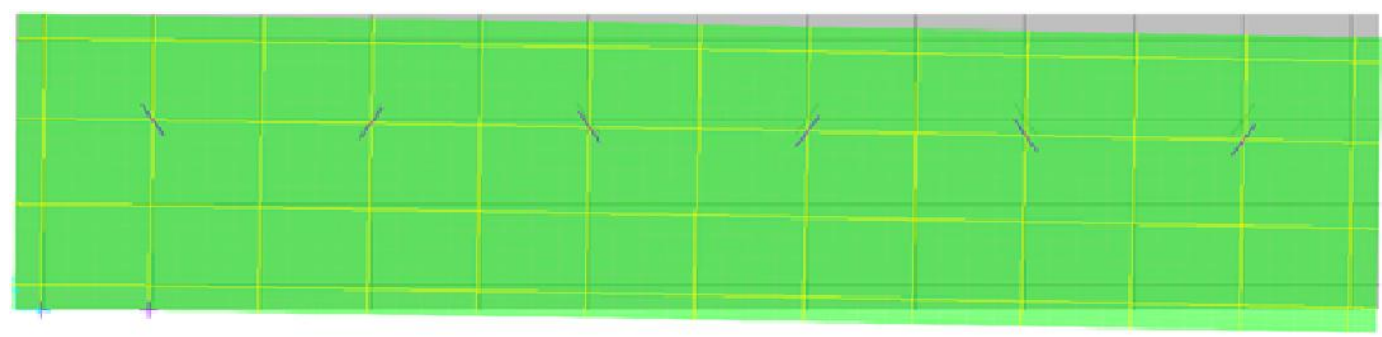

(b) $\mathrm{T}=0.73180$ detik; $\mathrm{f}=1.36649 \mathrm{~Hz}$

Gambar 11. Mode Shape Translasi (a) Pada Model A3 dan Mode Shape Rotasi Pada Model C3 (b) 


\section{KALIBRASI MODEL ANALISIS NUMERIK TERHADAP UJI VIBRASI}

Setelah dilakukan studi analisis numerik dari struktur dermaga dengan mengasumsikan berbagai macam variasi pemodelan, didapatkan bahwa dari 27 model hanya 2 yang mendekati hasil uji vibrasi. Meskipun demikian nilai dari 25 model yang lain menghasilkan batas nilai ragam getar (mode shape) yang berupa translasi dan rotasi. Dimana dari hasil berbagai pemodelan menghasilkan nilai frekuensi alami yang berkisar $0,49096 \mathrm{~Hz}$ sampai 5,58692 Hz untuk ragam getar translasi. Sedangkan untuk ragam getar rotasi menghasilkan nilai frekuensi alami yang berkisar 1,09790 Hz sampai 9,36327 Hz. Hasil tersebut dirangkum pada Tabel 7 dan Gambar 9.

Tabel 6. Rangkuman Hasil Studi Pemodelan Numerik Pada Struktur Dermaga

\begin{tabular}{ccc}
\hline \multirow{2}{*}{ Ragam Getar } & \multicolumn{2}{c}{ Frekuensi Alami $(\mathrm{Hz})$} \\
\cline { 2 - 3 } & Batas Bawah & Batas Atas \\
\hline Translasi & 0,49096 & 5,58692 \\
\hline Rotasi & 1,09790 & 9,36327 \\
\hline
\end{tabular}

Pemodelan numerik yang mendekati hasil tumbukkan lateral pada titik 2 pengujian vibrasi $(0,98$ $\mathrm{Hz}$ ) adalah sesuai dengan data perencanaan sebelumnya yaitu pada model A3 yang menghasilkan nilai frekuensi alami sebesar 0,90027 Hz. Dari analisis numerik menunjukkan bahwa data hasil pengujian tidak dapat dilakukan rata-rata karena hasil rata-rata menunjukkan nilai $1,2 \mathrm{~Hz}$.

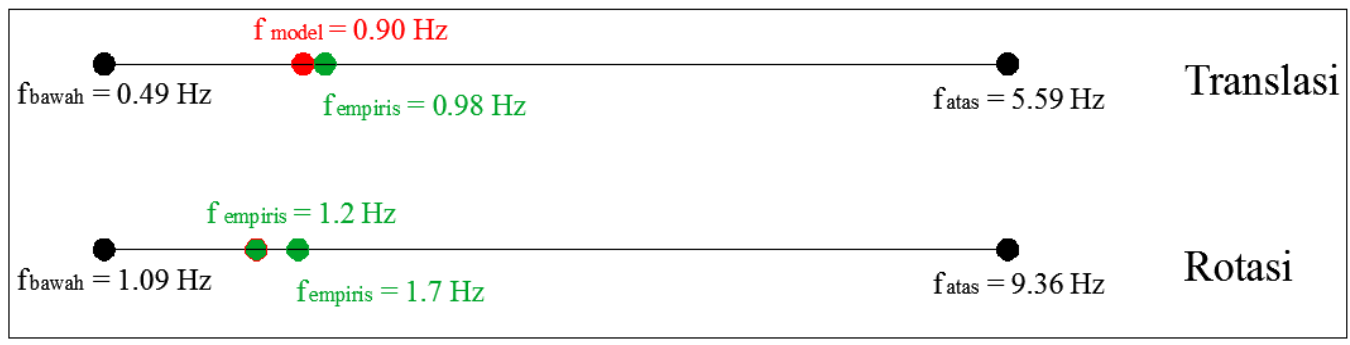

Gambar 12. Nilai Batas Atas Dan Batas Bawah Frekuensi Alami Struktur Dermaga

\section{KESIMPULAN}

Hasil uji vibrasi struktur Dermaga Donggala yang ada terdiri dari berbagai nilai frekuensi alami. Untuk memilah frekuensi alami yang tepat ternyata tidak sederhana. Dari berbagai hasil analisis secara numerik dapat dipahami bahwa setiap frekuensi alami adalah hasil dari berbagai pemodelan. Dari analisis yang telah dilakukan dapat dipahami bahwa frekuensi alami memiliki arah (mode shape) dan rentang nilai tertentu sesuai dengan pemodelannya dimana tentu saja harus dicocokan antara perilaku fisik sesuai pemodelan yang telah dilakukan. Dari hasil analisis secara numerik maka dapat disimpulkan :

a. Berdasarkan hasil evaluasi arah tumbukan kapal, strategi yang digunakan oleh surveyor dengan melakukan rata-rata tidak tepat karena untuk mempelajari data hasil pengujian vibrasi perlu mempelajari arah pemberian gaya, arah pemasangan dan penempatan sensor accelerometer serta perlu melakukan pengelompokan hasil pengujan vibrasi berdasarkan arah sensor sehingga sesuai dengan model analisis numerik.

b. Analisis numerik sangat membantu untuk memahami konstruksi secara keseluruhan sehingga dapat menentukan perilaku dari bangunan yang berkesesuaian dengan hasil uji vibrasi. 


\section{DAFTAR PUSTAKA}

Abdeljaber, O., Younis, A., Avci, O., Catbas, N., Gul, M., Celik, O., and Zhang, H. (2016) "Dynamic Testing of a Laboratory Stadium Structure." Geotechnical and Structural Engineering Congress, ASCE, DOI: 10.1061/9780784479742.147

Avci, O. (2012) "Retrofitting Steel Joist Supported Footbridges for Improved Vibration Response." Structures Congress, ASCE, DOI: 10.1061/9780784412367.041

Avci, O. (2015) "Modal Parameter Variations due to Joist Bottom Chord Extension Installation on Laboratory Footbridges." Journal of Performance Construction Facilities, DOI: 10.1061/(ASCE)CF.1943-5509.0000635

Avci, O., and Davis, B. (2015) "A Study on Effective Mass of One Way Joist Supported System." Structures Congress, ASCE, DOI: 10.1061/9780784479117.073

Brownjohn, JMW., Reynders, E., and Roeck, G de. (2010) "Dynamic Testing of Constructed Facilities." Structures Congress, ASCE, DOI: 10.1061/41130(369)53

Conte, J. P., He, Xianfei., Moaveni, B., Masri, SF., Caffrey, J P., Wahbeh, M., Tasbihgoo, F., Whang, D H., and Elgamal, A. (2008) "Dynamic Testing of Alfred Zampa Memorial Bridge." Journal of Structural Engineering, DOI: 10.1061/(ASCE)07339445(2008)134:6(1006)

Davis, B., and Avci, O. (2015) "Simplified Vibration Serviceability Evaluation of Slender Monumental Stairs.” Journal of Structural Engineering, DOI: 10.1061/(ASCE)ST.1943541X.0001256

Jeary, A. P., Winant, T., and Bunyan, J. (2015) "Some Aspects of the Measurement of Vibration Intensity for the Assessment of Building Structures." Forensic Engineering $7^{\text {th }}$ Congress Performance of the Built Environment

Morassi, A., and Tonon, S. (2008) "Dynamic Testing for Structural Identification of a Bridge." Journal of Bridge Engineering, DOI: 10.1061/(ASCE)1084-0702(2008)13:6(573)

Setareh, M. (2010) “Vibration Serviceability of a Building Floor Structure. I: Dynamic Testing and Computer Modeling." Journal of Performance of Constructed Facilities, DOI: 10.1061/(ASCE)CF.1943-5509.0000134

Setareh, M., and Gan, S. (2018) "Vibration Testing, Analysis, and Human-Structure Interaction Studies of a Slender Footbridge." Journal of Performance Construction Facilities, DOI: 10.1061/(ASCE)CF.1943-5509.000121

PT Graha Survei Indonesia, (2016) "Laporan Pemeriksaan Assessment dan Dynamic Test Dermaga Donggala Provinsi Sulawesi Tengah." Karawaci, Banten. 